\title{
Dorota Rybarkiewicz*
}

\section{ROZUMOWANIE METAFORYCZNE, CZYLI „METAFORĄ PO OCZACH”}

\begin{abstract}
Streszczenie. Według głównej tezy badań kognitywnych metafora jest podstawą myślenia. W kontekście prawa, które stanowi podstawę życia społecznego i ma wielki wpływ na każdego $\mathrm{z}$ nas, teza ta ma fundamentalne znaczenie. Zakres oddziaływania tej tezy określony jest $\mathrm{w}$ artykule poprzez charakterystykę trzech typów metafor. Są one też punktem wyjścia do sformułowania ogólnej definicji metafory, która pozwala dostrzec metaforyczność pewnych sytuacji pozornie z metaforą niemających nic wspólnego oraz związanych z nimi procesów rozumowania, które nazwane zostaną rozumowaniem metaforycznym.
\end{abstract}

Słowa kluczowe: prawo, metafora, model, perswazja, wnioskowanie metaforyczne.

W latach 70. XX w. w gabinetach dwóch ministrów zagranicznych: Stanów Zjednoczonych i Związku Radzieckiego, wisiały mapy świata. W pierwszym - dwie półkule, wschodnia i zachodnia, w drugim - mapa w odwzorowaniu walcowym z wielkim obszarem Związku Radzieckiego i krajów zależnych zaznaczonym na czerwono, pozostałe państwa w jednym mdłym kolorze. Mapy ilustrowały i wyznaczały sposób patrzenia na świat. Związek Radziecki w centrum świata, otoczony przez wrogie obszary, którym „należy nadać kolor”. Stany Zjednoczone na osobnej półkuli, bezpiecznie odizolowane od reszty świata i zdystansowane. Pytanie - czy to pies upodabnia się do właściciela, czy to właściciel dobiera psa podobnego do siebie - odnosi się przez analogię do map wiszących w gabinetach i... do metafor. Poniższy tekst ukazuje różne aspekty odpowiedzi na to pytanie.

Zawód prawnika jest ściśle związany ze słowem. Język prawniczy definiuje, wyjaśnia, uzasadnia, bada, rozumuje i perswaduje. Od starożytności prawnicy są świadomi, ile zależy z jednej strony od precyzyjnego i logicznego posługiwania się językiem, a z drugiej strony, jak wiele może osiągnąć ten, który jest bardziej biegły w stosowaniu zasad retoryki czy nawet chwytów erystyki. Wszystkie wymienione powyżej czynności mowy charakterystyczne dla prawa są zarazem przedmiotem badania logiki. Prawnicy, korzystając z badań logicznych języka naturalnego, starali się przestrzegać postulatów dotyczących

\footnotetext{
* Uniwersytet Łódzki, Instytut Filozofii, Katedra Logiki i Metodologii Nauk.
} 
poprawności logicznej wypowiedzi. Jeden z postulatów dotyczy unikania wyrażeń niedookreślonych, wieloznacznych i niezrozumiałych, a do takich niewątpliwie należy metafora. $Z$ drugiej strony metafora sprawia, że perswazja staje się bardziej skuteczna. Ambiwalencja metafory polega między innymi na tym przeciwstawieniu błędu logicznego i skuteczności perswazji. Rodzi ona pewien dysonans w praktyce stosowania metafor.

Wobec powyższego nie należy się dziwić, że w praktyce prawniczej metafora jest traktowana $\mathrm{z}$ podejrzliwością, a prawnik uczciwie dążący do prawdy obiektywnej ma być zwolennikiem stanowiska Hobbesa, że metafora zwodzi na manowce i powinna być wyeliminowana. Według takiego poglądu metaforę należy „przetłumaczyć” na fakty, w przeciwnym razie prowadzi ona do błędu i może zmylić. Jeżeli metafora ma być użyteczna, to tylko jako środek krasomówczy, jako że „wprowadza ożywienie i urozmaica styl”, przy czym jej poetyckość może zaszkodzić jasności i zrozumiałości. Przekonaniom tym towarzyszy wiara, że łatwo jest odseparować metaforę od języka dosłownego i że jesteśmy w stanie wyeliminować ją z dyskursu.

Dbałość o precyzję i poprawność języka prawa natrafiła na poważne wyzwanie w zetknięciu z kognitywną teorią metafory, według której metafory są inherentne dla języka i myślenia. Jeśli umysł myśli metaforami, jak twierdzi np. Lakoff ${ }^{1}$, to jak unikać metafor i czy w ogóle jest to celowe i możliwe? Przeprowadzone poniżej rozgraniczenie poszczególnych typów metafor i obszarów ich działania przybliża odpowiedź na to pytanie.

$\mathrm{Z}$ bogactwa różnych rodzajów metafor opisanych w literaturze przedmiotu w ciągu ostatnich lat przywołane zostaną trzy główne. One bowiem decydują o ważnych granicach oddzielających:

1) jak mówimy od tego, co mówimy (formę od treści);

2) świadome głoszenie pewnych treści od ich nieświadomego głoszenia.

\begin{tabular}{l|c|c}
\multicolumn{2}{|c}{ FORMA } & \multicolumn{2}{|c}{ TREŚĆ } \\
JAK MÓWIMY & CO MÓWIMY \\
& ŚWIADOMIE & NIEŚWIADOMIE \\
METAFORA & METAFORA- & METAFORA \\
PUNKTOWA & -MODEL & POJĘCIOWA
\end{tabular}

Schemat. Typy metafor i ich własności

Źródło: opracowanie własne.

${ }^{1}$ G. Lakoff, Women, Fire, and Dangerous Things, University of Chicago Press, Chicago 2008. 


\section{METAFORA PUNKTOWA}

Metafora punktowa związana jest z formą wypowiedzi (co nie oznacza, że nie przekazuje żadnej treści). Utożsamiana jest z ozdobą, wyszukanym środkiem stylistycznym służącym raczej do ubarwienia i urozmaicenia tekstu niż do rzetelnego przekazu informacji. Pomimo aury artystycznej lekkości metafora punktowa świetnie sprawdza się w sytuacjach, gdy potrzebny jest bardziej intuicyjny i szybki wgląd w daną sprawę - pomaga zrozumieć i służy wyjaśnianiu².

„Prawidłowo sporządzone uzasadnienie wyroku powinno być garniturem uszytym na miarę, a nie garniturem pierwszym lepszym zdjętym w sklepie z wieszaka, który może kupić każdy klient i będzie jakoś pasował"’.

„Bezczynny tryb życia żony-lalki może w zasadzie wywołać rozkład pożycia. Przy ocenie jednak tego związku przyczynowego należy mieć na uwadze całokształt stosunków materialnych i psychicznych małżonków"4.

Plastyczne obrazy garnituru i lalki oraz wszystkie związane z nimi cechy, takie jak: wygoda/ niewygoda, świetny/kiepski wygląd, podkreślenie atutów/braków fizycznych w pierwszym wypadku oraz postać urodziwej, lecz bezwolnej i płytkiej kobiety w drugim, niosą ze sobą cały wachlarz skojarzeń i konotacji emocjonalnych. Czasem niespodziewanie obraz garnituru może skutkować następującym przeniesieniem: pragnienie podziwu związanego z wyglądem (elegancki garnitur na miarę) rozszerzy się poprzez skojarzenie na sferę wykonywanych zadań (uzasadnienie wyroku). Podobnie w przypadku „lalki” pojawić się mogą różne skojarzenia związane np. z bohaterką powieści pod tym tytułem albo nawet z samą książką. Jeśli nudziła nas i wzbudzała niechęć, to takie konotacje emocjonalne mogą zostać przeniesione na żonę-lalkę, której sprawa toczy się właśnie przed sądem. Do tych pozornie przypadkowych powiązań i ich skutków jeszcze powrócimy.

Nie sposób jednak nie zauważyć, że jeśli naprawdę chce się podać warunki, jakie musi spełniać „prawidłowo sporządzone uzasadnienie wyroku” albo konkretnie rozstrzygnąć, w jaki sposób żona przyczyniła się do rozkładu pożycia małżeńskiego, to poprzestanie na powyższych metaforach punktowych jest dalece niewystarczające. Przykład fragmentu przesłuchania:

„- Skąd Pani o tym wiadomo?

- Podsłuchałam jego strumień świadomości”.

\footnotetext{
${ }^{2}$ Metafora punktowa jest nie tylko figura stylistyczna czy retoryczną.

${ }^{3}$ Z uzasadnienia wyroku NSA z 28 kwietnia 2005 r., OSK 1468/04; https://pl-pl.facebook. com/CiekaweOrzeczenia/posts/753381551345202 (dostęp: 2.05.2015).

${ }^{4}$ Orzeczenie SN z dnia 18 sierpnia 1955 r., II CR 1082/54, PiP 1956, z. 2, s. 393; https://www. facebook.com/CiekaweOrzeczenia/posts/763650523651638?stream_ref=5 (dostęp: 2.05.2015).
} 
pokazuje to jeszcze wyraźniej. Czy można mieć pewność, co dokładnie miała na myśli autorka powyższego stwierdzenia? Klarowność wypowiedzi zależy od stopnia świeżości metafor: metafory żywe są mniej jasne niż metafory martwe (konwencjonalne) i bez dalszego zbadania i refleksji nie wiadomo, co mogą znaczyć. „Strumień świadomości”, który ma odnosić się do źródła informacji, z pewnością brzmi niedorzecznie, ale czy takie wyrażenie specyficznie jurydyczne, jak ,duch prawa" usłyszane po raz pierwszy nie brzmiałoby nawet bardziej dziwnie? To głównie świeże metafory mieli na myśli Lock i Hobbes, zakazując ich używania w filozofii i nauce (choć sami tym zakazem nie czuli się objęci).

Logika języka naturalnego wskazuje na brak precyzji zarówno żywych, jak i martwych metafor punktowych (jeśli te drugie uda się rozpoznać). Jak już wspomniano, poprzestawanie na wyrażeniach metaforycznych powoduje często niedookreśloność, na przykład w wypowiedziach: „Sprawiedliwość określa prawo” albo „Podstawą sprawiedliwości jest prawo” niedosłowne znaczenie wyrażeń „określa” oraz ,podstawa” w tym kontekście nie pozwala na jednoznaczne i jasne stwierdzenie, jaka właściwie relacja zachodzi między prawem a sprawiedliwością. Negatywne skutki użycia takiej frazy metaforycznej w sformułowaniach prawnych są aż nadto oczywiste. Metafora powinna najpierw zostać dookreślona, czyli sparafrazowana w języku dosłownym, aby mogła stać się zdaniem w sensie logicznym. $Z$ tego powodu stwierdzenie, że metafora jest fałszem, bo gdyby była w sposób dosłowny prawdziwa, nie byłaby metaforą, nie jest adekwatne. Nie sposób orzekać ani prawdziwości, ani fałszywości o niedookreślonej wypowiedzi metaforycznej. Ponadto, gdyby nawet tak czynić, zauważmy, że zanegowana metafora pozostaje metaforą, choć dosłownie jest zdaniem prawdziwym: „Jestem twoją zabawką. Nie jestem twoją zabawką".

Warto podkreślić, że nie każda wypowiedź metaforyczna jest uznawana za błąd niedookreśloności, np.:

„Dopuszczalne jest nabycie prawa wieczystego użytkowania przez zasiedzenie biegnace przeciwko poprzedniemu wieczystemu użytkownikowi”.

„Koncerny międzynarodowe stosują miękkie prawo”.

W reprezentowanych przypadkach zastosowanie wyrażenia w funkcji metaforycznej uzasadnione jest zaistnieniem luki semantycznej. W momencie braku terminu w języku dla określenia danej rzeczy lub zjawiska powszechną praktyką

${ }^{5}$ Analiza tej metafory zob. T. Kotuk, Metafory w polskim dyskursie prawniczym z perspektywy lingwistyki kognitywnej, „Przegląd Sądowy” 2012, 10; www.polaczenie-spolek.wolterskluwer. $\mathrm{pl}$ /artykuly-prawnicze/metafory-w-polskim-dyskursie-prawniczym-z-perspektywy-lingwistyki-kognitywnej,264.html (dostęp: 7.03.2015). 
jest zapożyczenie na zasadzie analogii słowa już istniejącego, tym samym rozszerzając jego denotację lub znaczenie. Proces ten nazwany katachrezą zostawił wiele śladów zarówno w języku potocznym (głowa kapusty, głowa rodu, ucho dzbanka, miękkie serce), jak i prawniczym (ramię sprawiedliwości, prawo dalsze, w granicach prawa). Katachreza uznawana jest za istotną funkcją metafory ${ }^{6}$. W powyższych przykładach terminy: „biegnące przeciwko”, „miękkie”, choć użyte metaforycznie, to jako przypadki katachrezy nie podlegają kryteriom prawdziwościowym, tak jak nadanie nazwy im nie podlega - definicja projektująca nie może być uznana za adekwatną ani za nieadekwatną.

Metafora punktowa jest jednak całkowicie rehabilitowana jako narzędzie perswazji ${ }^{7}$. Takie zastosowanie metafory zalicza się do Sztuki. Arystoteles przyjmował trzy założenia dotyczące metafory. Po pierwsze był zdania, że umiejętność dostrzegania podobieństwa, konieczna, aby metafory tworzyć i rozumieć, jest sztuką i wymaga talentu. Wobec tego jedni go mają, inni nie. Wynika z tego drugie założenie, że nie można się nauczyć sztuki posługiwania się metaforami. Nie każdy może być rzeźbiarzem w kamieniu i nie każdy może rzeźbić w języku. Z nich z kolei wynika trzeci aspekt: metafora stanowi specjalne użycie języka polegające na odejściu od jego normalnego funkcjonowania. Traktuje się więc metaforę jako rodzaj słownej sztuczki. Arystoteles docenia metaforę jako środek retoryczny, bowiem metafora może przyciągnąć uwagę słuchaczy. Podobna ze swej natury do zagadki powoduje zaciekawienie, chęć znalezienia rozwiązania, co wzbudza pozytywne uczucia odbiorcy. A o nie często przemawiającym chodzi.

Przychylne zainteresowanie słuchacza nie wyczerpuje możliwości perswazyjnego wpływu metafory. Znane jest dokonywanie za pomocą metafory zmiany postaw $^{8}$ oraz perswazyjne redefiniowane poprzez zmianę konotacji ${ }^{9}$. Metafora punktowa jest sposobem mówienia, ale takim, który sprawia, że ludzie zaczynają myśleć i działać inaczej niż dotychczas. Badania Sopory \& Dillard potwierdzają spostrzeżenia, że metafora w większym stopniu zmienia postawę odbiorcy niż ta sama treść przekazana dosłownie. Mniej znane są ich dalsze wnioski, które stanowią gotowy przepis na sukces perswadowania za pomocą

${ }^{6}$ Nie przez wszystkich filozofów języka katachreza łączona była z metaforą. Według niektórych zwolenników (np. John Searle) podejścia substytucyjnego głoszących, że wyrażenie metaforyczne zastępuje wyrażenie dosłowne, metafora musi z definicji posiadać parafrazę w języku dosłownym (np. „oskarżony jest bryłą lodu” = „oskarżony jest nieemocjonalny”), którego to warunku katachreza spełnić nie może.

${ }^{7}$ Wskazuje na to chociażby obfitość literatury na ten temat.

${ }^{8}$ Zob. np. J. W. Bowers, M. M. Osborn, Attitudinal Effects of Selected Types of Concluding Metaphors in Persuasive Speeches, „Speech Monographs” 1981, 33, s. 147-155; J. T. Johnson, S. E. Taylor, The Effect of Metaphor on Political Attitudes, „Basic and Applied Social Psychology” 1981, 2, s. 305-316.

${ }^{9}$ Zob. np. T. Pawłowski, Tworzenie pojęć i definiowanie w naukach humanistycznych, PWN, Warszawa 1978. 
metafory. Warto je więc tu przytoczyć: (1) użycie jednej metafory powoduje większą zmianę postawy niż wielu metafor; (2) większy wpływ mają metafory występujące na początku tekstu; (3) świeże metafory wpływają mocniej niż znane; (4) metafory usłyszane mają przewagę nad przeczytanymi; (5) stosowanie metafor podnosi ocenę nadawcy, a zwłaszcza postrzeganie jego dynamizmu (dynamizm jest jednym z trzech komponentów wiarygodności, obok kompetencji i charakteru i wiąże się ze stopniem, w jakim słuchacze podziwiają i identyfikują się z atrakcyjnością, siłą i energią mówcy); (6) metafory rozgałęzione (extended) powiększają zmianę postawy (metaforę rozgałęzioną stanowi pewna liczba metafor mających wspólną podstawę); (7) lepsza znajomość dziedziny docelowej metafory zwiększa jej wpływ na postawy odbiorcy; (8) niska początkowa wiarygodność wzrasta po użyciu metafory bardziej niż wyższa początkowo wiarygodność.

Skutkiem niedocenianym jest zmiana toku rozumowania poprzez zmianę metafory punktowej. Cykl eksperymentów przeprowadzonych przez Thibodeau, Boroditsky dotyczył zastosowania dwóch różnych metafor do opisu tego samego problemu i sprawdzenia, czy proponowane rozwiązania będą takie same.

„Zbrodniarze są dzikimi bestiami polującymi na ulicach naszego miasta...”

„Zbrodniarze niczym wirusy rozprzestrzenili się po całym naszym mieście... (po kropkach następuje szczegółowy opis zbrodni)"”10.

Podawane środki zaradcze okazały się wynikać z użytej metafory: w pierwszym przypadku przestępcy są „tropieni”, „,chwytani”, „,urządza się na nich zasadzki”, „eksterminuje”; w drugim proponuje się działania zwykle związane ze zwalczaniem epidemii: ,izolację”, „ochronę”, „zabezpieczenie”. Pierwsza metafora implikuje zatajenie informacji o grasującym przestępcy z obawy, aby nie zdradzić się z zastawioną pułapką; druga wręcz przeciwnie - skłania do publicznego ostrzegania przed zagrażającym niebezpieczeństwem. Fakt, że w pewnym mieście amerykańskim policja przyjęła tę pierwszą metaforę i nie zdradziła przed społeczeństwem obszaru działania gwałciciela nieletnich okazał się tragiczny w skutkach. Komentując ten przypadek, Kelling napisał (metaforycznie), że „dziewczynki padły ofiarą metafory"11.

${ }^{10}$ Podane przykłady mogą być jednocześnie zaliczone do drugiego typu metafory-modelu. Nierozłączność podziału wynika z faktu, że konkretna metafora może jednocześnie występować w różnych rolach.

${ }^{11}$ Cyt. za: P. H. Thibodeau, L. Boroditsky, (2011), Metaphors We Think With: The Role of Metaphor in Reasoning, http://journals.plos.org/plosone/article?id=10.1371/journal.pone. 0016782 (dostęp: 6.04.2015). 


\section{METAFORA-MODEL}

Nobilitacja metafory nastąpiła wraz z obserwacją, że pozwala ona na wysnuwanie analogii, co więcej, otwiera na nowe analogie tak pożądane w tworzeniu teorii naukowych. Max Black ${ }^{12}$ zauważył jej funkcje jako model (naukowy). Model zostaje (arbitralnie) wprowadzony do rozważań naukowych, stając się źródłem inspiracji w poszukiwaniu odpowiedzi na niewyjaśnione dotychczas kwestie, np. atom to „układ planetarny” i od tego momentu bada się jego implikacje wyrażone w języku adekwatnym do przyjętego modelu (np. elektrony „krążą” po „orbitach”). Model tak określony jest również rodzajem metafory żywej i stosuje się go nie tylko w nauce. Również prawnicy opracowujący dany przypadek tak naprawdę tworzą „teorię” z nim związaną, czyli proponują model, którego elementy i struktura ,przefiltrują" dane, wyznaczając ramę (strukturę) i kanalizując (ukierunkowując ,channel") wiedzę i percepcję odbiorcy. Ukierunkowanie łączy się z szerszym działaniem mającym na celu wyjaśnienie lub zapoznanie z nowością. Zawsze polega ono na tym, co stanowi istotę metafory, czyli na spojrzeniu na jedną rzecz poprzez drugą, na mówieniu o jednej rzeczy w kategoriach drugiej (Black ${ }^{13}$, Lakoff, Johnson). W zależności od tego, czym konkretnie te rzeczy są i jaką mają strukturę, mamy w rezultacie wiele możliwości „kanalizowania”: od filtrowania do nadawania struktury. Metaforą posłużyć się może adwokat, który chce zwrócić uwagę na wadliwą kategoryzację czynu swojego klienta wypływającą przede wszystkim ze stereotypu ${ }^{14}$. Stereotypy często wynikają z nieuświadomionych, a przyjętych w języku modeli mówienia o jednej rzeczywistości w kategoriach innej. Spójrzmy przykładowo na metafory prawa imigracyjnego, które mówią o imigrantach w kategoriach ,inwazji obcych zalewających” ${ }^{15}$ społeczeństwo albo ,skażenia”, albo ,zaśmiecenia”, co implikuje niebezpieczeństwo, atak, zagrożenie pogorszenia bądź utraty dotychczasowych warunków życia. Imigranci grożą ,eskalacją” (lawiną) żądań, a kraj musi się przed nimi „,chronić”. Pojawiają się pytania, czy ,walka z” imigracją ,będzie przegrana"? I groźba stojąca za tym pytaniem jest jak samospełniająca się przepowiednia. Bowiem metafory są nie tylko słowami, lecz także wpływają na to, jak myślimy o danym zagadnieniu, uwypuklając pewne cechy, a zacieniając inne, a w przypadku problemu wyznaczają potencjalne rozwiązania (tzw. metafory generatywne ${ }^{16}$ ).

${ }_{12}$ M. Black, Models and Archetypes, [w:] A. Ortony (red.), Models and Metaphors, Cornell University Press, Ithaca-New York 1962, s. 219-243.

${ }_{13}$ M. Black, Metaphor, [w:] A. Ortony (red.), Models and Metaphors, Cornell University Press, Ithaca-New York 1962, s. 25-48.

${ }_{14}$ P. A. Wilkins, Confronting the Invisible Witness: The Use of Narrative to Neutralize Capital Jurors'Implicit Racial Biases, „West Virginia Law Review” 2012, vol. 115, s. 331-332.

${ }^{15} \mathrm{~K}$. Cunningham-Parmeter, Alien Language: Immigration Metaphors and the Jurisprudence of Otherness, „Fordham Law Review”, April 5, 2011, vol. 79, s. 15-45.

16 D. A. Schön, Generative metaphor: A perspective on problem-setting in social policy, [w:] A. Ortony (red.), Metaphor and Thought, Cambridge University Press, Cambridge 1994, s. 137-163. 
Metafory-modele reprezentują konkurencyjne punkty widzenia, czasem bardzo od siebie odległe. Przyjęcie jednego z nich ma daleko idące konsekwencje, a nawet łączy się z ryzykiem zgody na ograniczenie sposobu interpretacji otaczających zjawisk. Każdy model-metafora niesie ze sobą określone założenia i hipotezy. Takie skutki widoczne są ze szczególną ostrością w prawie dotyczącym traktowania imigrantów. Sytuacja może ulec poprawie, dopiero gdy w sposób świadomy negatywne modele zostaną zastąpione nowymi, np. w odniesieniu do imigrantów wprowadzi się metafory osadzone w szerszym kontekście migracji ludów oraz korzyści kulturowych i ekonomicznych z tego wynikających ${ }^{17}$. Posługiwać się można na przykład obrazami „napływu świeżych sił”, „odnowy”, „ubogacenia”.

Ciekawy przykład zmiany modelu (reframing) podaje Wilkins w charakterystyce linii obrony mordercy i dealera narkotykowego na dużą skalę. Jego adwokat przeciwstawia stereotypowym schematom łączonym z takimi przestępstwami, trzy inne. Pierwszy, który ma utorować główny tok myślenia poprzez torowanie (priming), odwołuje się do metafory „dziecka bożego”; drugi przedstawia oskarżonego jako człowieka nieprzystającego do stereotypowego obrazu przestępcy; trzeci jest spojrzeniem na niego poprzez soczewkę ,ojca chroniącego swe dzieci”. Pierwszy model wprowadza perspektywę transcendentną, dzięki której można nabrać dystansu w ocenie. Drugi ma na celu zablokowanie podążania za automatycznie narzucającym się tokiem myślenia o „ludziach tego pokroju”. Ten trzeci model jest szczególnie istotny, ponieważ, jeśli osoby wydające werdykt znajdą na początek nawet niewielkie podobieństwo między oskarżonym a „opiekuńczym ojcem", to powstaje szansa, że pozostałe pozytywne cechy tego drugiego zostaną również przeniesione na tego pierwszego, przynajmniej w zakresie konotacji emocjonalnych, co może się okazać wystarczające do wydania korzystnego werdyktu. Powyższy proces (zmian wywołanych przez mowę obrońcy) złożony z trzech etapów: zdystansowania się, zablokowania stereotypu oraz skojarzenia pozytywnego, może być wywołany również przy pomocy innych metafor/modeli, które dodatkowo mogą być dostosowywane do konkretnego kontekstu (społecznego, kulturowego czy prawnego), co służyć będzie wzmocnieniu pożądanego efektu.

Model stanowi mniej lub bardziej trafne przybliżenie do rzeczywistości. Jednak nawet naukowcy nie mają innego sposobu opisu świata. Warto w tym miejscu zauważyć, że przystawanie modelu do świata, zakłada jego istnienie, więc wpisuje się w korespondencyjną teorię prawdy (a nawet może być traktowane jako metoda zbliżania się do odkrywania platońskiej prawdy). 


\section{METAFORA POJĘCIOWA (KONCEPTUALNA)}

Zwykliśmy uważać, że skoro kodeksy, konstytucje czy zwykłe orzeczenia nie prowadzą do zupełnie dowolnych ocen postępowania obywateli, to jest to między innymi dowód na logiczną poprawność zawartych w nich przepisów i postanowień, co także oznacza brak takich „min” jak metafory. Odkrycie metafor pojęciowych przez Lakoffa i Johnosona zburzyło to przekonanie, przede wszystkim dlatego, że ich istnienie jest przed nami ukryte. Działanie ich przebiega w odwrotnym kierunku niż działanie modelu. Żaden użytkownik języka ich nie wybrał, a skutki ich stosowania na nasze poznanie, świadomość, wiedzę i decyzje, choć znaczące, są powszechnie mylone z „twardą rzeczywistością”.

Metafora pojęciowa, będąc pojęciem nadrzędnym wobec metafor językowych (punktowych) pozostaje w ich cieniu, użytkownicy języka nie uświadamiają sobie jej istnienia i nie wiedzą (bez specjalnych wskazówek), jak do nich dotrzeć. Przykładowo do metafory pojęciowej: MYŚLENIE TO PODRÓżOWANIE prowadzą metafory językowe: „doszedł do wniosku”, „,znalazł proste rozwiązanie”, „jego myśl biegła ku"; natomiast metaforę pojęciową: SĄDZENIE TO MIERZENIE wygenerujemy z metafor językowych: ,miarą jego uczynków jest...., „,miarka się przebrała...”.

O wyroku, który bez wątpienia jest aktem mowy, tylko czasem mówi się w ten sposób: „,ogłosić wyrok”, „potwierdzić wyrok" i to niekonsekwentnie, gdyż nie mówi się: „,wypowiedzieć wyrok” - a przecież akty mowy z definicji są wypowiedziami. Częściej mówimy o wyroku jak o specyficznym przedmiocie, który można utrzymać, podtrzymać, uchylić i który zapada. Jeśli ktoś przygląda się osobom wstawiającym duże okno, to mógłby komentować ich czynności właśnie za pomocą takich czasowników. A tymczasem używane są one do opisu procedury sądowej: „sąd uchylił wyrok”, „wydał wyrok”, ,podtrzymał wyrok”, „utrzymać w mocy”, ,wyrok zapadł”. Czy rodzaj ludzki zdradza się tu ze swoistym poczuciem humoru, czy stoją za takim przeniesieniem inne nieodkryte mechanizmy, bo trudno doszukać się analogii czy podobieństwa wprost. Trudno też powiedzieć, jaki wpływ może mieć metafora konceptualna WYROK TO PRZEDMIOT (podobny do okna) na podejmowanie decyzji o wyroku czy na nasz stosunek do niego. Są jednak metafory konceptualne, które niewątpliwie oddziałują na naszą percepcję i stosunek do danego zagadnienia i, co ważniejsze, na sposób podejmowanych działań. Należy do nich chociażby sztandarowy przykład ARGUMENTACJA TO WOJNA: „,był bezbronny wobec jej argumentów”, „dobiła go tym słowem”, „wyszedł zwycięsko ze wszystkich potyczek słownych ze swymi przeciwnikami”, ,zaatakował go tym pytaniem"... Pytanie, jak wyglądałby świat naszych dysput, gdyby zastąpić tę metaforę innymi - ARGUMENTACJA TO WSPÓŁPRACA, ARGUMENTACJA TO POSZUKIWANIE (PRAWDY) - choć banalne i z pozoru retoryczne w konkretnych realiach językowych, jest jednak rodzajem triangulacji, przynosząc alternatywne możliwości patrzenia i działania. 
Ciekawe rezultaty może przynieść znalezienie alternatywy dla metafor konceptualnych dotyczących prawa: (1) PRAWO TO OBIEKT, (2) PRAWO TO RELACJA WERTYKALNA, (3) PRAWO TO OBSZAR ${ }^{18}$, których przejawem językowym są martwe metafory językowe: (1) „mieć prawo” (2) „być ponad prawem”, (3) „przekroczyć granice prawa". Zwłaszcza nasze rozumienie relacji pomiędzy prawem a sprawiedliwością ujawnić by się mogło dopiero dzięki zmianie metafory konceptualnej. „Jeśli sprawiedliwość często konceptualizowana jest jako bycie «pod» prawem, to właściwe znaczenie tej konceptualizacji dla funkcjonowania prawa poznane zostanie wówczas, gdy będzie można dokonać zmiany konceptualizacji na inną" 19 - czyli gdy uda się wprowadzić inny model. Wydaje się ponadto, że uświadomić sobie możemy owo działanie tylko wtedy, gdy „oddalamy się" od starej metafory, dzięki nowej. Taka świadoma triangulacja (tj. wprowadzenie nowego modelu) przynosi nie tylko odmienny wgląd, ale w ogóle umożliwia zobaczenie dotychczasowej perspektywy, czyli metafory konceptualnej, w której uwięziona była nasza dotychczasowa percepcja. Stworzenie nowego modelu-metafory, nowej struktury odniesień, nie jest jednak sprawą prostą, o czym świadczy chociażby historia nauki. „Prace badawcze są naprawdę jak wędrówka we mgle. Nie wiesz, dokąd idziesz. Szukasz po omacku. Potem ludzie dowiadują się o wszystkim i już po fakcie wydaje się im, że było to bardzo proste" ${ }^{20}$. Zarówno opisana trudność znalezienia modelu, jak i jego „oczywistość" po tym fakcie, mają swoje źródło między innymi w mechanizmie tworzenia i rozumienia metafor.

Wraz z teorią metafory konceptualnej uległy osłabieniu milcząco przyjmowane założenia teorii modeli implikujące korespondencyjną teorię prawdy. Metafora pojęciowa jako narzędzie myślenia ma często za punkt zaczepienia doznania cielesne $^{21}$, wobec czego świat zewnętrzny, aczkolwiek bywa ich przyczyną, odsunięty został na plan dalszy. W powstałą szczelinę wsunęły się subiektywizm, relatywizm, pragmatyzm (w tym skuteczność perswazji), ponieważ podobieństwa nie tkwią już w samych rzeczach, jak chce obiektywizm, ale ważne są jedynie podobieństwa, jakich doświadczają ludzie (Lakoff i Johnson).

Część metafor konceptualnych mających swe źródło w doznaniach fizjologicznych, cielesnych, psychicznych wpływa na procesy legislacyjne ${ }^{22}$. Mowa o metaforach, które są zakotwiczone w ciele (embodied), np. radość odbieramy jako lekkość, ruch w górę, smutek - odwrotnie, wagę kojarzymy z wielkością,

18 S. Larsson, Justice 'Under' Law: The Bodily Incarnation of Legal Conceptions Over Time, „International Journal for the Semiotics of Law” 2014, no. 27, s. 613-626.

19 Ibidem, s. 624.

${ }^{20}$ Wypowiedź Francisa Cricka (odkrywcy wraz Jamesem Watsonem podwójnej helisy DNA) zacytowana w J. Horgan, Koniec nauki, Prószyński i S-ka, Warszawa 1999, s. 204.

${ }^{21}$ Ang. embodiment.

${ }^{22}$ E. J. Percy, J. L. Hoffmann, S. J. Sherman, Sticky Metaphors and the Persistence of the Traditional Voluntary Manslaughter Doctrine, „Journal of Law Reform” 2011, vol. 44: 2, s. 383-427. 
złość z gorącem, ciśnieniem i czerwienią, miłość z trzepotaniem, drżeniem, co znajduje wyraz w licznych powiedzeniach: „unosi się z radości”, „ma doła”, „zawrzał (ze złości)”, „serce mu trzepotało”. Sama cielesna natura ogranicza nas w wyborze metafor zwłaszcza, gdy dotyczą emocji. Ten rodzaj metafor nie jest wybierany arbitralnie, więc nie można zastąpić ich przez inne metafory, dlatego nazwane zostały „przylepnymi” (sticky) ${ }^{23}$. W kontekście praktyki legislacyjnej posiadają one tę cechę, że blokują zmiany procedur prawnych ${ }^{24}$.

Przykładem takiej sztywności prawnej wynikającej z ukrytej u jej podstaw konceptualnej metafory przylepnej jest tradycyjna doktryna zabójstwa, według której silne wzburzenie, złość mogą prowadzić do zachowania wysoce agresywnego, w wyniku którego dochodzi do zabójstwa w afekcie. Psychologia potwierdza to założenie, ale dokładniejsze badania nad emocjami pokazują jednocześnie, że jest to jedynie jedna z możliwych ścieżek reakcji. W wielu innych przypadkach w pierwszej fazie po prowokującym zdarzeniu - do nich tradycyjnie zalicza się bezpośredni atak fizyczny oraz złapanie żony w dwuznacznej sytuacji in flagran$t i$ - dochodzi do zamrożenia emocjonalnego i dopiero po pewnym czasie, nawet długim, jak kilka dni czy tygodni, osoba wcześniej spokojna i wydawałoby się pogodzona traci poczytalność. Przepisy prawne nie uwzględniają w tym przypadku wyników badań psychologicznych. Pomijają też sytuacje, w których motorem zbrodni są uczucia inne niż agresja, np. lęk czy strach. Tych uczuć wobec stresujących gwałtownych sytuacji doznają w większym stopniu kobiety. Percy, Hoffmann wysuwają przypuszczenie, że brak zmian przepisów w tym zakresie jest skutkiem zakorzenienia metafory przylepnej ${ }^{25}$ i wyjaśniają to następująco: metafora przylepna sięga korzeniami do reakcji fizjologicznych. Kiedy mówimy: „zagotowało się we mnie”; „zawrzało”; „,czuję, że zaraz wybuchnę”; „nerwy mi puściły”; „mam czerwono przed oczyma”; „posypały się iskry (pioruny) z oczu”, odwołujemy się do kolejnych odczuwanych doznań fizycznych towarzyszących silnej złości i de facto w sposób metaforyczny opisujemy te zmiany. Co więcej, jesteśmy $\mathrm{w}$ stanie wyrazić słowami nasze emocje tylko pośrednio, za pomocą słów odnoszących się do kolejnych „zmian towarzyszących” zachodzących w organizmie. Odczucia te wspólne są dla wszystkich (zdrowych) ludzi i tak mocno skojarzone z danym uczuciem, że wygenerowane metafory wydają się naturalne i oczywiste. Nieświadomie też poddajemy się ich implikacjom. Co konkretnie pociąga za sobą pojęciowa metafora ZŁoŚĆ TO GORĄC, ZŁOŚĆ TO CIŚNIENIE, ZŁOŚĆ TO OGIEŃ (BURZA)? W przypadku pierwszych dwóch przypominamy garnki z gotującą się cieczą, w wyniku czego rośnie temperatura i ciśnienie. Wiemy, że każdy garnek, nawet największy, ma ograniczoną wytrzymałość i w pewnym momencie wybuchnie. Człowiek też ma swoją wytrzymałość na „rosnące ciśnienie złości”

\footnotetext{
23 Ibidem, s. 385.

24 Ibidem.

25 Ibidem, s. 403.
} 
i zrozumiałe jest, że jeśli agresor nie zaprzestanie swych działań w porę, to grozi to wybuchem. Na tym podobieństwo się nie kończy. Garnek stygnie powoli i potrzebny jest czas, aby „pokrywka przestała stukać” - tak samo człowiek potrzebuje czasu, aby jego wzburzenie zmalało, aby ostygnąć z emocji. Wykres tego zdarzenia podnosiłby się stromo na początku po szybkim osiągnięciu wartości maksymalnej długą łagodną linią opadał w dół. Problem polega na tym, że nie dla wszystkich ludzi ten właśnie wykres byłby charakterystyczny, ponieważ ich reakcje emocjonalne przebiegają według innego schematu: emocje narastają powoli i najwyższe ich nasilenie jest odroczone w czasie. Mogą minąć godziny, a nawet dni od zdarzenia, kiedy odczuwana złość pozbawia kogoś poczytalności. A jednak dokonane wówczas zabójstwo osądzane będzie raczej bez uwzględnienia czynnika emocjonalnego. Ta druga ścieżka reakcji nie wpisuje się w stosowaną metaforę, w czym upatruje się przyczynę pewnego zamrożenia prawodawstwa $\mathrm{w}$ tej kwestii.

Należy w tym miejscu zauważyć, że drugim, podobnym do doznań cielesnych, filtrem ograniczającym zmianę jest kultura ukształtowana przez interakcję między człowiekiem i jego środowiskiem ${ }^{26}$.

\section{METAFORYCZNA STRONNICZOŚĆ}

Zarówno metafora-model, jak i metafora konceptualna mają wpływ na to, co mówimy, ponieważ stoją u podstaw tworzonych pojęć i kategorii poznawczych. Obie są pokrewne metaforom doktrynalnym Smitha i do obu odnoszą się jego słowa, że oddziałują najsilniej i dlatego są najbardziej niebezpieczne. Z tym, że metafory modele służą do myślenia poza schematami (out of the box), zaś metafory pojęciowe są przejawem myślenia schematycznego (canyon thinking) ${ }^{27}$. Wiele praw wyrażonych jest w kategoriach metaforycznych: na przykład rozdział państwa od Kościoła wyraża się w prawie amerykańskim poprzez metaforę „wysokiego muru separacji”. Haig Bosmajian ${ }^{28}$ uważa tę metaforę za wyjątkową dla zrozumienia roli metafor w podejmowaniu decyzji przez sędziów. Omawia wiele orzeczeń i opinii prawnych zbudowanych wprost na tej metaforze. Dla ilustracji podamy przytoczony przez niego fragment uzasadnienia decyzji sędziego Frank-

${ }^{26}$ Z. Kövecses, Metaphor in Culture: Universality and Variation, Cambridge University Press, Cambridge 2005.

${ }^{27}$ D. Rybarkiewicz, Out of the Box Thinking, [w:] P. Łukowski, A. Gemel, B. Żukowski (red.), Cognition, Meaning and Action, Łódź University Press \& Jagiellonian University Press, ŁodźKraków, s. 146-159.

${ }^{28}$ H. A. Bosmajian, Metaphor and Reason in Judicial Opinions, Southern Illinois University Press, Carbondale 1992, s. 73. 
furtera w sprawie lekcji religii w szkole ${ }^{29}$ : „Separacja oznacza separację, nic innego. Metafora Jeffersona opisująca relację pomiędzy Kościołem a Państwem mówi o «ścianie separacji» a nie o cienkiej linii, którą łatwo przekroczyć. [...] Jeśli już nie gdzie indziej, to w relacji pomiędzy Kościołem a Państwem «dobre płoty czynią dobrymi sąsiadami» (good fences make good neighbours)". Metafora ta pozwala myśleć o tym rozdziale jako o „nieprzeniknionym i wysokim murze”, a o próbach współpracy jako o „precedensach powodujących korozję, niszczenie muru”. Brak muru zaś kojarzony jest z czymś rozmazanym, niejasnym, mętnym, zmiennym, gdzie punkt styku działania Kościoła i państwa jawi się jako „syzyfowa praca dopasowania do siebie łatek" ${ }^{30}$. Z drugiej strony autor cytuje też sędziów, którzy opowiadając się za prawem do nauki religii w szkole, mówią wprost, że „istnieją wydatne różnice między ogólnikowym stwierdzeniem dotyczącym rozdziału kościoła od państwa a opisem jego wniosków dotyczących edukacji. Reguły prawne nie powinny być wyciągane z figur mowy"31.

Czy są jakieś niepisane prawa stosowania metafor w prawie? Mówiąc o prawach stosowania metafor powinno się rozważać jej wszystkie trzy rodzaje. Pomimo że podzielają mechanizm działania, pojawiają się w różnych funkcjach i na odrębnych płaszczyznach dyskursu. Spośród trzech metafor tylko metaforę punktową przeciwstawiano zasadzie jasnego wyrażania myśli i postulat wykluczenia metafor z języka prawniczego, naukowego, filozoficznego tylko ich dotyczył. Metafory-modele uznać należy za nieodzowny element rozumienia i zdobywania wiedzy. Są narzędziami twórczego myślenia. Natomiast metafory konceptualne są przejawem ludzkiego mechanizmu poznawczego utrwalonym w martwych metaforach punktowych, językowych. Metafory pojęciowe funkcjonują podobnie jak modele, ale zwykli użytkownicy języka nie zdają sobie z tego sprawy.

Kiedy prawnicy, zwolennicy realizmu, przyznają, że metafory mogą „uwalniać” myśl, jednocześnie obawiając się, że „zniewalają” myśl, to mówią prawdopodobnie o dwóch różnych typach metafor: modelu i konceptualnej ${ }^{32}$. I kiedy dążą do tego, aby pozbawić język prawniczy metafor i w ten sposób uczynić go tak precyzyjnym, aby umożliwiał przeprowadzanie poprawnych rozróżnień i podejmowanie właściwych decyzji, to mogą to praktycznie uczynić tylko w stosunku do metafor punktowych.

Powyższe typy metafor wskazują na bardzo szeroki zakres tego terminu oraz ujawniają zasadniczą ambiwalencję, która polega na tym, że z jednej strony dostrzega się w nich figurę retoryczną, zabieg stylistyczny, dodający szlifu wygłaszanym mowom prawniczym, a z drugiej - uznaje się za słuszne twierdzenie Johnsona, że metafora jest „figurą życia”, „figurą myśli”. Znajduje to swoje

\footnotetext{
29 Ibidem, s. 74.

30 Ibidem, s. 76.

31 Ibidem.

32 Może tu też chodzić o manipulacyjną perswazję za pomocą metafor.
} 
odzwierciedlenie w praktyce prawniczej, gdzie oficjalnie nie uznaje się wpływu języka na werdykty, a faktyczna obecność licznych metafor w tekstach prawniczych każe sądzić, że jest inaczej. Czym zatem jest metafora, jeśli może być zarazem figurą retoryczną i (aż) figurą myśli?

Termin „metafora”, pomimo że rozumiany jest szeroko, jednocześnie może być dość precyzyjnie określony w następujący sposób: metafora jest zjawiskiem językowo-poznawczym, które można opisać, odwołując się do trzech pojęć Arystotelesa: przeniesienia, podobieństwa i przekształcenia. Dla prostoty warto przybliżyć te pojęcia na przykładzie metafory językowej (punktowej): metafora językowa jest wyrażeniem złożonym, gdzie jedno z wyrażeń składowych zostało przeniesione poza swój zwyczajny kontekst użycia, czyli w tym przypadku można powiedzieć, że połączone jest z wyrażeniem nieprzeniesionym relacją niestandardowej konkatenacji. Znaczenie całej konkatenacji generowane jest na podstawie podobieństwa ${ }^{33}$ między „tym wszystkim, co za tymi wyrażeniami stoi i do czego one odsyłają". Niestety wielość teorii metafor nie dała w rezultacie jednoznacznej nazwy dla elementów porównywanych, dlatego najlepiej przywołać tu najpowszechniej używane terminy wywodzące się z lingwistyki kognitywnej: dziedzina (domena) źródłowa oraz dziedzina (domena) docelowa (utożsamiana z tym, o czym mowa). W wyniku porównywania obu dziedzin pierwotne znaczenie wyrażeń z nimi związanych ulega przekształceniu, w większym stopniu to, które zostało przeniesione i które jednocześnie odsyła do dziedziny źródłowej.

Transponując powyższe określenie metafory na wyższy poziom ogólności, można powiedzieć, że metafora jest takim współwystępowaniem obiektów, które w akcie porównywania uzyskują (nowe) znaczenie. Struktura metafory jest dwuwarstwowa $^{34}$. W warstwie pierwszej, bezpośrednio dostępnej zmysłom, obiekt pierwszy jest połączony z obiektem drugim nierealną ${ }^{35}$ „,konkatenacją? (dotyczy to wszystkich metafor). Innymi słowy obiekty tak naprawdę niespotykane razem występują obok siebie w jednych ramach przestrzenno-czasowych. W przypadku metafor żywych połączone są nierealną i niestandardową ${ }^{36}$ „konkatenacją”. Rela-

${ }^{33}$ Zagadnienie podobieństwa metaforycznego jest bardzo szerokie. Zauważmy jedynie, że podobieństwo metaforyczne cechuje niesymetryczność, która przejawia się w zmianie znaczenia wyrażenia metaforycznego przy odwracaniu kolejności wyrażeń składowych, np. „Jego słowa są mieczami. Jego miecze są słowami. On zanurzył się w problemie. Problem zanurzył się w nim".

34 D. Rybarkiewicz, The Structure of Metaphor: Towards a Pragmatic Approach, „Logica Trianguli" 1998, 2, 103-115.

${ }^{35}$ Nierealność w przypadku metafor oznacza niedosłowność w szerokim znaczeniu, czyli obejmuje metafory martwe (np. ,głowa domu” dosłownie jest nierealna). W przypadku metafor wizualnych oznacza zestawienie w obrębie jednej przestrzeni (obrazu, sceny, budynku) elementów niespotykanych normalnie razem, np. nogi hipopotama i karoseria samochodu tworzące jeden obiekt.

${ }^{36}$ Niestandardowość wiąże się z niedosłownością w ścisłym znaczeniu; nie uwzględnia metafor martwych, czyli związków frazeologicznych w typie: łańcuch zdarzeń, syn był oparciem dla matki, czarny humor czy głowa domu. 
cja tworząca drugą warstwę struktury metafory polega na porównywaniu ze sobą dziedzin: źródłowej i docelowej.

Warto w tym miejscu zauważyć, że według badań psychologii kognitywnej poznawanie i myślenie ma u swych podstaw porównywanie. Istotą myślenia jest analogia - twierdzi znany psycholog kognitywny Hofstadter. Powszednim doświadczeniem jest jednak to, że otoczeni jesteśmy mnóstwem przedmiotów i odbieramy bardzo wiele bodźców, wcale ich nie porównując. Do szukania podobieństw między nimi musimy być w jakiś sposób sprowokowani przez samą percypowaną materię. Potrzebny jest swoisty „wyzwalacz”. Wydaje się, że w przypadku metafory językowej takim wyzwalaczem jest pojawiający się dysonans: fakt wypowiedzenia nonsensu semantycznego, który (pozornie) łamie regułę konwersacyjną: „Mów do rzeczy!” ${ }^{37}$ w zestawieniu z przekonaniem, że jeśli ktoś coś mówi, to zapewne ma jakiś cel, chce coś przekazać. Natomiast metafora-model wiąże się z bardziej bezpośrednim wezwaniem do szukania ukrytych podobieństw i analogii ze względu na kontekst, w jakim się pojawia. To sama ciekawość badacza uruchamia proces porównywania (oczywiście obecne też jest zderzenie semantyczne, bo przecież atom to nie układ słoneczny). W końcu w metaforach pojęciowych napotykamy porównania już w jakimś stopniu utrwalone, tj. zapisane w strukturach mózgu. Jako takie pojawiają się one na początku całego procesu „obróbki danych”, na który składają się: (1) aktywacja schematów poznawczych, (2) integracja nowych danych oraz (3) dopasowanie do nowych danych, czyli uaktualnienie lub zmiana schematów ${ }^{38}$. Mózg musi sobie poradzić $\mathrm{z}$ chaosem napływających bodźców, dlatego na podstawie odbieranych percepcji tworzy struktury, do których na zasadzie podobieństwa dopasowuje napływające wrażenia i informacje. Metafora konceptualna jest już strukturą zapisaną, pozostałe metafory napływają w strumieniu odbieranych informacji. Nie można w jej przypadku mówić o wyzwalaczu, ale raczej o wpływie jej schematów na percepcję i myślenie. Takim utrwalonym porównaniem nie tylko mówimy i myślimy, lecz także według jego kanonu tworzymy nowe, świeże metafory ${ }^{39}$. W pewnym sensie stanowi ona treść naszych założeń o świecie; aby się o tym przekonać wystarczy się cofnąć w rozwoju języka i znaleźć moment, gdy danej metafory pojęciowej jeszcze nie było, np. sprawiedliwość i prawo nie określały się wzajemnie, a firmy nie były osobami ${ }^{40}$.

${ }^{37}$ P. Grice, Logika i konwersacja, przeł. J. Wajszczuk, „Przegląd Humanistyczny” 1977, z. 6; D. Sperber, D. Wilson, Relevance: Communication and Cognition, Blackwell, Oxford 1986.

${ }^{38}$ H. Marcus, R. B. Zajonc, The Cognitive Perspective in Social Psychology, [w:] G. Lindzey, E. Aronson (red.), The Handbook of Social Psychology, $3^{\text {rd }}$ ed., Random House, New York 1985, s. $137-229$.

${ }^{39}$ Okazuje się, że większość oryginalnych metafor w poezji jest dopasowana do istniejących metafor konceptualnych. Polega więc na ubraniu starych treści w nowe słowa.

${ }^{40}$ Czy za postęp uznaje się przyrost porównań? 
Wyzwalacz, tak jak porównanie, jest pojęciem zrelatywizowanym do osoby, bowiem zależy od już istniejących schematów poznawczych danej jednostki. Wyzwalaczem porównań mogą więc stać się pozornie nic nieznaczące dane płynące z otoczenia. Wyobraźmy sobie sytuację, w której pewien sędzia został właśnie zdradzony przez ukochaną, długowłosą szatynkę noszącą zazwyczaj niebieskie ubrania. Akurat kilka dni po tym przykrym zdarzeniu sędzia ten prowadzi sprawę rozwodową, w której oskarża się o zdradę małżeńską - przypadek chciał, że długowłosą szatynkę ubraną akurat w niebieską marynarkę. Czy nie jest prawdopodobne, że w umyśle sędziego obudzą się wspomnienia i skojarzenia? Czy można przypuszczać, że może on doświadczyć pewnego „rezonansu” emocjonalnego ${ }^{41}$ i nawet jeśli jest świadomy jego oddziaływania, że to z kolei może w jakimś stopniu wpłynąć na kierunek jego myślenia, a nawet na końcowe decyzje?

W efekcie porównania pojawiają się nie tylko cechy wspólne, lecz także konkretne myśli, sądy, przekonania, intuicje i uczucia. Nasz umysł je nieustannie aktywuje i generuje (m.in. poprzez operacje logiczne, ale nie tylko) szukając podobieństwa, analogii między tym, co jest nowe a tym, co jest już w nim zapisane. Następnie dokonuje meta-porównywań: między wynikiem poprzedniego porównania i znów tym, co już ma w swych zasobach. Porządkowanie danych polega na ich dopasowaniu do schematów pojęciowych (albo na modyfikacji lub tworzeniu nowych w obliczu braku gotowych). W kontekście podejmowania decyzji nowy bodziec (czasami jest to na przykład metafora-model, innym razem argument, melodia lub kolor sukienki) może uaktywnić różne schematy poznawcze zapisane w mózgu zależnie od tego, które jako pierwsze:

- ulegną aktywacji (primacy);

- przyciągną uwagę (salience);

- będą najłatwiej i najszybciej dostępne w pamięci (accessibility) ${ }^{42}$.

W sytuacji opisanej powyżej wygląd kobiety funkcjonuje jak wyzwalacz określonej struktury w mózgu i sprawia, że w kontekst procesu sądowego mózg przenosi byłą ukochaną wraz ze wszystkim, co się z nią spontanicznie kojarzy. Stwierdzenie dalszego podobieństwa odbywa się jakby siłą inercji. Przeksztalceniu ulec więc może na początek stosunek emocjonalny sędziego do pozwanej, za czym pójść może ocena (np. mając dwie hipotezy do wyboru, z powodu przeniesienia i na podstawie podobieństwa, wybierze jedną i z niej uczyni przesłankę dalszego rozumowania). Oczywiście przekształceniu ulec może też wiedza, nie tylko emocje, na przykład, gdy na podstawie zdjęcia posesji (dom otynkowany na czarno i ogrodzony wysokim litym murem) „,nasuwa się nam opinia” na temat właściciela; albo przeniesienie wiedzy o podobnych wcześniejszych przypadkach pod wpływem przypadkowego drobiazgu, np. znalezionego kolczyka ${ }^{43}$ (typowe

\footnotetext{
${ }^{41}$ Tzw. efektu przeniesienia.

42 R. J. Crisp, R. N. Turner, Essential Social Psychology, wyd. 3, Sage Publications, London 2014.

${ }^{43}$ Jak w powieści Nory Roberts, Zorza polarna.
} 
myślenie przez analogię w powieściach kryminalnych, gdy jakiś szczegół sytuacji działa jak wyzwalacz, nagle pozwalając rozwiązać zagadkę). Co więcej, cały proces myślowy odbywa się automatycznie, bezrefleksyjnie i jego rezultaty mogą być korygowane jedynie post factum. Jak widać to, co doprowadza sędziego do sformułowania wniosków, ma cechy mechanizmu charakterystycznego dla metafor.

Rozumowanie jest procesem, $w$ którym używa się argumentów, przesłanek i pewników $w$ celu określenia czy dane zdanie jest prawdziwe czy fatszywe. Jeśli to metafora tworzy przesłankę, jak w sytuacjach opisanych powyżej, to całe rozumowanie możemy nazwać metaforycznym. W wymienionych przypadkach $\mathrm{z}$ neutralnego (obojętnego) poziomu emocji przechodzi się w kierunku jednego z biegunów pozytywnego bądź negatywnego, albo z zerowego poziomu wiedzy („,nie wiem”) przechodzi się na poziom „wiem, że...”. Nabyta w ten sposób emocja lub wiedza prowadzą pośrednio lub bezpośrednio do przyjęcia przesłanek. Metafora może prowadzić do wniosków i przekonań, których nie osiąga się na drodze rozumowania przebiegającego zgodnie z logiką. Co więcej, nie da się do końca przewidzieć, w jakim kierunku „pobiegną” myśli danej osoby i do jakich konkretnie sądów doprowadzi ją rozumowanie metaforyczne. Czy właśnie z tego powodu przestrzegano prawników przed ciemną stroną metafory $?^{44}$

Przykład prawa pokazuje, że metafory wpływają nie tylko na percepcję, myślenie, lecz że ich wpływ idzie dalej - możemy nawet mówić o rozumowaniu metaforycznym. Widoczna jest siła ich oddziaływania, jednak z jakiś względów każdy jest przekonany, że sam jest wolny od ich wpływu (tzw. efekt trzeciej osoby ${ }^{45}$ ). Żywimy złudzenie, że jesteśmy odporni na ich ukrytą siłę perswazji, tymczasem nawet nasze rozumowanie bezrefleksyjnie podporządkowuje się metaforom. Jedyną bronią jest uświadomienie sobie tych mechanizmów - taki cel przyświeca niniejszej pracy. Bez tego nie ma szans na korygowanie skutków oddziaływania metafor.

\section{BIBLIOGRAFIA}

Black Max. 1962. Metaphor. W Models and Metaphors. Red. Ortony Andrew. 25-48. Ithaca-New York: Cornell University Press.

Black Max. 1962. Models and Archetypes. W Models and Metaphors. Red. Ortony Andrew. 219243. Ithaca-New York: Cornell University Press.

${ }^{44} \mathrm{~Np}$. Lord Mansfield: „nothing in law is so apt to mislead as a metaphor”, cytat: Lord Westbury w Knox v. Gye (1872) Law Reports, vol. 5, series HL (House of Lords), pp. 656-675, cyt. za: Craig, s. 326.

${ }^{45}$ Efekt trzeciej osoby ujawnia się, gdy ludzie są przekonani, że inni w większym stopniu niż oni sami podejmują działania nieaprobowane społecznie, więc to inni są podatni na perswazję, manipulację i propagandę, ulegają złudzeniom i wszelkim słabościom i to innych metafora zwodzi na manowce. W. Phillips Davison, The Third-Person Effect in Communication, „Public Opinion Quarterly" 1983, 47 (1), s. 1-15. 
Bosmajian Haig. 1992. Metaphor and Reason in Judicial Opinions. Carbondale: Southern Illinois University Press.

Bowers John Waite, Osborn Michael. 1981. „Attitudinal Effects of Selected Types of Concluding Metaphors in Persuasive Speeches". Speech Monographs 33: 147-155.

Cunningham-Parmeter Keith. 2011. „Alien Language: Immigration Metaphors and the Jurisprudence of Otherness". Fordham Law Review 79: 15-45.

Craig Rotherham. 2002. Proprietary Remedies in Context. Oxford: Bloomsbury Publishing.

Crisp Richard, Turner Rhiannon. 2014. Essential Social Psychology. Thousand Oaks, CA: Sage Publications.

Davison Phillips. 1983. „The Third-person Effect in Communication”. Public Opinion Quarterly 47 (1): 1-15.

Grice Herbert Paul. 1977. „Logika i konwersacja”. Przeglad Humanistyczny 21 (6): 85-99.

Hazel Marcus, Zajonc Robert B. 1985. The Cognitive Perspective in Social Psychology. W The Handbook of Social Psychology. Red. Lindzey Gardner, Aronson Elliot. 137-229. New York: Random House.

Hofstadter Douglas R. 2001. Analogy as the Core of Cognition. W The Analogical Mind: Perspectives from Cognitive Science. Red. Genter Dedre, Holyoak Keith James, Kokinov Boicho N. 499-538. Cambridge, MA: MIT Press.

Johnson Joel T., Taylor Sheley. E. 1981. „The Effect of Metaphor on Political Attitudes”. Basic and Applied Social Psychology 2: 305-316.

Kelling George. 1991. „Crime and Metaphor: Toward a New Concept of Policing”. City Journal 1. www.city-journal.org/html/issue1_5.html (dostęp: 8.11.2015).

Kotuk Tadeusz. 2012. „Metafory w polskim dyskursie prawniczym z perspektywy lingwistyki kognitywnej" Przeglad Sadowy 10. www.polaczenie-spolek.wolterskluwer.pl/artykuly-prawnicze/metafory-w-polskim-dyskursie-prawniczym-z-perspektywy-lingwistyki-kognitywnej,264.html (dostęp: 7.03.2015).

Kövecses Zoltán. 2005. Metaphor in Culture: Universality and Variation. Cambridge: University Press.

Lakoff George, Johnson Mark. 1988. Metafory w naszym życiu. tł. Krzeszowski Tomasz P. Warszawa: Państwowy Instytut Wydawniczy.

Lakoff George. 2008. Women, Fire, and Dangerous Things. Chicago: University of Chicago Press.

Larsson Stefan. 2013. Justice 'Under' Law: The Bodily Incarnation of Legal Conceptions Over Time. www.soclaw.lu.se/en/stefanlarsson/publication/4178656 (dostęp: 22.03.2015).

Pawłowski Tadeusz. 1978. Tworzenie pojęć i definiowanie w naukach humanistycznych. Warszawa: Państwowe Wydawnictwo Naukowe.

Percy Elise J., Hoffman Joseph L., Sherman Steven J. 2011. „Sticky Metaphors and the Persistence of the Traditional Voluntary Manslaughter Doctrine". Journal of Law Reform 44 (2): 383-427.

Rotherham Craig. 2002. Proprietary Remedies in Context. Oxford, Portland: Hart Publishing.

Rybarkiewicz Dorota. 1998. „The Structure of Metaphor: Towards a Pragmatic Approach”. Logica Trianguli 2: 103-115.

Rybarkiewicz Dorota. 2015. Out of the Box Thinking. W Cognition, Meaning and Action. Red. Łukowski Piotr, Gemel Aleksander, Żukowski Bartosz. 146-159. Łodź-Kraków: Łódź University Press \& Jagiellonian University Press.

Schön Donald A. 1994. Generative metaphor: A perspective on problem-setting in social policy. W Metaphor and Thought. Red. Ortony Andrew. 137-163. Cambridge: University Press.

Searle John R. 1994. Metaphor. W Metaphor and Thought. Red. Ortony Andrew. 92-124. Cambridge: University Press.

Smith Michael R. 2007. „Levels of Metaphor in Persuasive Legal Writing”. Mercer Law Review 58: 919-948. 
Sopory Pradeep, James Price Dillard. 2002. Figurative Language and Persuasion. W The Persuasion Handbook: Developments in Theory and Practice. Red. Dillard James Price, Pfau Michael. 407-426. Thousand Oaks, CA: Sage Publications.

Sperber Dan, Wilson Deirdre. 1986. Relevance: Communication and Cognition. Oxford: Basil Blackwell.

Thibodeau Paul H., Boroditsky Lera. 2011. Metaphors we Think With: The Role of Metaphor in Reasoning. http://journals.plos.org/plosone/article?id=10.1371/journal.pone.0016782 (dostęp: 6.04.2015).

Wilkins Pamela A. 2012. „Confronting the Invisible Witness: The Use of Narrative to Neutralize Capital Jurors' Implicit Racial Biases”. West Virginia Law Reviev 115: 305-362.

\title{
Dorota Rybarkiewicz
}

\section{METAPHORICAL REASONING}

\begin{abstract}
That metaphors are a part of law seems to be commonplace nowadays. Nevertheless, the extent of their influence is not commonly acknowledged. The three types of metaphors: (1) verbal, point metaphors, (2) systemic, thinking changing, model metaphors and (3) hidden systemic, conceptual metaphors are here associated with the distinction between what is said and how it is said and between a conscious and unconscious message delivery - all of them of particular relevance to a legal discourse. Not all types of metaphors can (and should) be dispensed with. In some negative cases the only way to reduce their adverse effects is to provide tools to detect them. The definition proposed may serve this purpose. As an illustration, the paper points to some ordinary situation giving rise to metaphoric reasoning which leads to quite unpredictable (misleading) conclusions.

Keywords: law, metaphor, model, persuasion, metaphorical reasoning.
\end{abstract}

